Article

\title{
Feed and Disease at Olive Flounder (Paralichthys olivaceus) Farms in Korea
}

\author{
Joo-Young Jung ${ }^{1, *}$, Soohwan Kim ${ }^{1}$, Kyochan Kim ${ }^{1}{ }^{1}$, Bong-Joo Lee ${ }^{2}$, Kang-Woong Kim ${ }^{2}$ \\ and Hyon-Sob Han ${ }^{1, *}$ \\ 1 Faculty of Marine Applied Biosciences, Kunsan National University, 558 Daehak-ro, Gunsan, \\ Jeonbuk 54150, Korea; soohwan@kunsan.ac.kr (S.K.); chan1028@kaist.ac.kr (K.K.) \\ 2 Aquafeed Research Center, National Institute of Fisheries Science, 2600 Haean-ro, Chongha-myun, Buk-gu, \\ Pohang, Gyeongsangbuk-do 37517, Korea; bonglee@korea.kr (B.-J.L.); kangwoongkim@korea.kr (K.-W.K.) \\ * Correspondence: jyjung@pukyong.ac.kr (J.-Y.J.); smartfish@kunsan.ac.kr (H.-S.H.); \\ Tel.: +82-63-469-1834 (J.-Y.J. \& H.-S.H.)
}

Received: 23 June 2020; Accepted: 10 July 2020; Published: 14 July 2020

check for updates

\begin{abstract}
The objective of this study was to conduct field experiments comparing formulated (extruded pellets (E.P)) and raw-fish (moist pellets (M.P)) feeds at two flounder aquaculture farms for six months to obtain the basic data necessary for improving aquafarmers' awareness of feed-quality issues and firmly establish and expand the use of formulated feed. According to the results, the M.P group was higher in weight gain, feed efficiency ratio, protein efficiency ratio, and specific growth rate and lower in mortality rate than the E.P group. All cases of mortality were caused by six kinds of disease, four of which (Vibrio sp., Edwardsiella sp., Streptococcus sp., and Scuticociliates) were common to the two groups, whereas Lymphocystis arose only in the M.P group and abdominal inflation only in the E.P group at both farms. As for mortality in the present experiment, the numbers were 1047 at Da-Hae farm and 1167 at Global farm, with more fish dying in the E.P tanks than in the M.P tanks. By multiplying the number of deaths by selling price, the economic losses were $\$ 9650$ and $\$ 10,756$, respectively. Therefore, it should be considered an urgent priority to develop flounder-exclusive formulated feed for improved digestion and absorption rate and also to establish a water-quality-improvement management plan.
\end{abstract}

Keywords: olive flounder in Korea; moist pellets; extruded pellets; Lymphocystis; abdominal inflation

\section{Introduction}

Marine aquaculture has developed rapidly around the world, and is now regarded as an essential component of the global marine food supply. Global aquaculture production increased approximately three-fold, from 26.7 million metric ton in 1996 to 73.8 million metric ton in 2014, and in that year, fish accounted for $44 \%$ of global production from capture fisheries and aquaculture [1,2]. In the Republic of Korea, which ranked 7th among the world's top 25 aquaculture producers in 2014, flounder, the most produced fish, accounted for $46.2 \%$ (37,240 metric ton) of the total fish farming yield ( 80,530 metric ton) in 2018 [3].

A variety of interdisciplinary studies entailing selective breeding for improvement of growth $[4,5]$, feed [6-8], and vaccine development [9-13] have been carried out to develop flounder as a national strategic breed. The government has been promoting the use of formulated feeds since 2004 in order to develop a sustainable aquaculture industry. One result of this development is the Standard Guide Book, which was published in 2006 for olive flounder (Paralichthys olivaceus) culturing and again in 2007 for rockfish (Sebastes schlegeli); it includes information on aquaculture technology, techniques, and processes such as fish farming, parenting management, seedling production, nurturing management, feeding 
systems, disease control, and economic analysis of regional and scale forms. Despite such efforts, however, the use of formulated feed for fish farming in 2018 was only $23 \%$ (155,897 metric ton) of total fish feed $(670,631$ metric ton), while the rate at flounder farms accounted for only $7.5 \%$ (20,656 metric ton) of total flounder feed (274,599 metric ton) consumed at flounder farms [14].

In developed countries, the aquaculture industry and economy has been revitalized by, in part, the development and distribution of low-cost high-quality/efficiency formulated feeds through long-term field experiments. In Japan, for example, changes in awareness of the use of formulated feed by aquaculture producers due to increasing raw-fish feed have encouraged active formulated feed research and development by feed companies, which has led to a reduction in feed prices. In Norway, overall aquaculture costs have been reduced by reducing fishmeal content in feed from 75 to $20-25 \%$ in salmon farming. The utilization rate of formulated feed is more than $90 \%$ for red sea bream and salmon at Japanese and Norwegian farms, respectively, and more than $65 \%$ for yellow tail/amberjack at Japanese farms. [15]. However, in Korea, despite the various problems incurred by the use of raw fish feed (i.e., moist pellets (M.P)), which include, for example, overfishing of small fish such as anchovies, sardines, and herring, and deterioration of water quality and environmental pollution, M.P is still preferred at flounder farms due mainly to its low cost and high growth rate effect for flounder compared with formulated feed (i.e., extruded pellets (E.P)) [16].

Therefore, the objective of this study was to conduct field experiments comparing formulated (E.P) and raw-fish (M.P) feeds at two flounder aquaculture farms to obtain the basic data necessary for improving aquafarmers' awareness of feed-quality issues and firmly establish and expand the use of formulated feed.

\section{Results and Discussion}

\subsection{Evaluations of Extruded Pellet (E.P) and Moist Pellet (M.P) Systems for Fish-Growth Performance}

The growth performance and body compositions of the flounder fed with either of the two diets (E.P or M.P) are provided in Table 1 and Figure 1. The monthly weight gain rate relative to the stock weight (78.0 g) at Da-Hae was 56\% (August), 221\% (September), 437\% (October), 625\% (November), and $765 \%$ (December) in the control group (M.P) and in the experimental group (E.P) it was $56 \%$ (August), 155\% (September), 300\% (October), 473\% (November), and 606\% (December). Meanwhile, the rate of monthly weight gain rate relative to the stock weight (113.8 g) at Global was $47 \%$ (August), 198\% (September), 291\% (October), 434\% (November), and 472\% (December) in the control group (M.P) and in the experimental group (E.P) it was 44\% (August), 170\% (September), 271\% (October), $367 \%$ (November), and $401 \%$ (December). Overall, there was a significant difference in the values of weight gain (WG), feed efficiency ratio (FE), protein efficiency ratio (PER), and specific growth rate (SGR) between the two diets at both farms.

Protein in feed for flounder is important to meet amino acid and energy requirements, since this carnivorous fish has high protein availability but low carbohydrate and fat availability [17-19]. The results of relevant previous studies [20-27] indicated that the range of protein requirements varied according to fish size (4-307 g); however, the difference in protein content between the two feeds (> 59.9\% in the present study) was not considered to have affected fish growth, given the fact that the range of protein content in feed was $45-60 \%$ as well as the Fish Weight theory's contention that the correlation between fish growth and protein content in diet is not always proportional $(40 \%$, flounder) [18]. In studies on lipid supply in feed [28-32], the proper requirements for lipids also varied (9-17\%) according to fish size (18-597 g); however, as the lipid content in the feed increased, fish growth and the lipid contents in the fish whole body tended to be higher. Therefore, in the present study, the higher growth (Table 1 and Figure 1A,B) and lipid contents in the whole body (Table 1) of the fish in the control group (M.P) relative to the experimental group (E.P) was considered to have been due to their feed's high lipid content. 
Cholesterol, a major component of the cell membranes of animal cells, is a lipid found mainly in animal tissues. It is reported that it plays an important role in the immune system as a precursor of hormone and vitamin D [33,34]. Previous studies have shown that an increase in blood cholesterol by addition of fat sources in feed improved the disease resistance and immunity of fish against the pathogen Aeromonas hydrophila [35] and improved immune cell activation [36]. Indeed, the lipid content in feed and blood cholesterol are correlated, and, accordingly, the higher value of blood cholesterol in the fish in the control group (M.P) compared to those in the experimental group (E.P) was considered to have been due to the difference in the lipid contents between the two feeds (Table 2 and Figure 1C,D).

Table 1. Growth performance, feed efficiency, and whole-body proximate composition at the end of the 5-month experiment at two farms raising olive flounder fed with experimental diets (extruded pellets (E.P) and moist pellets (M.P)) ${ }^{1}$.

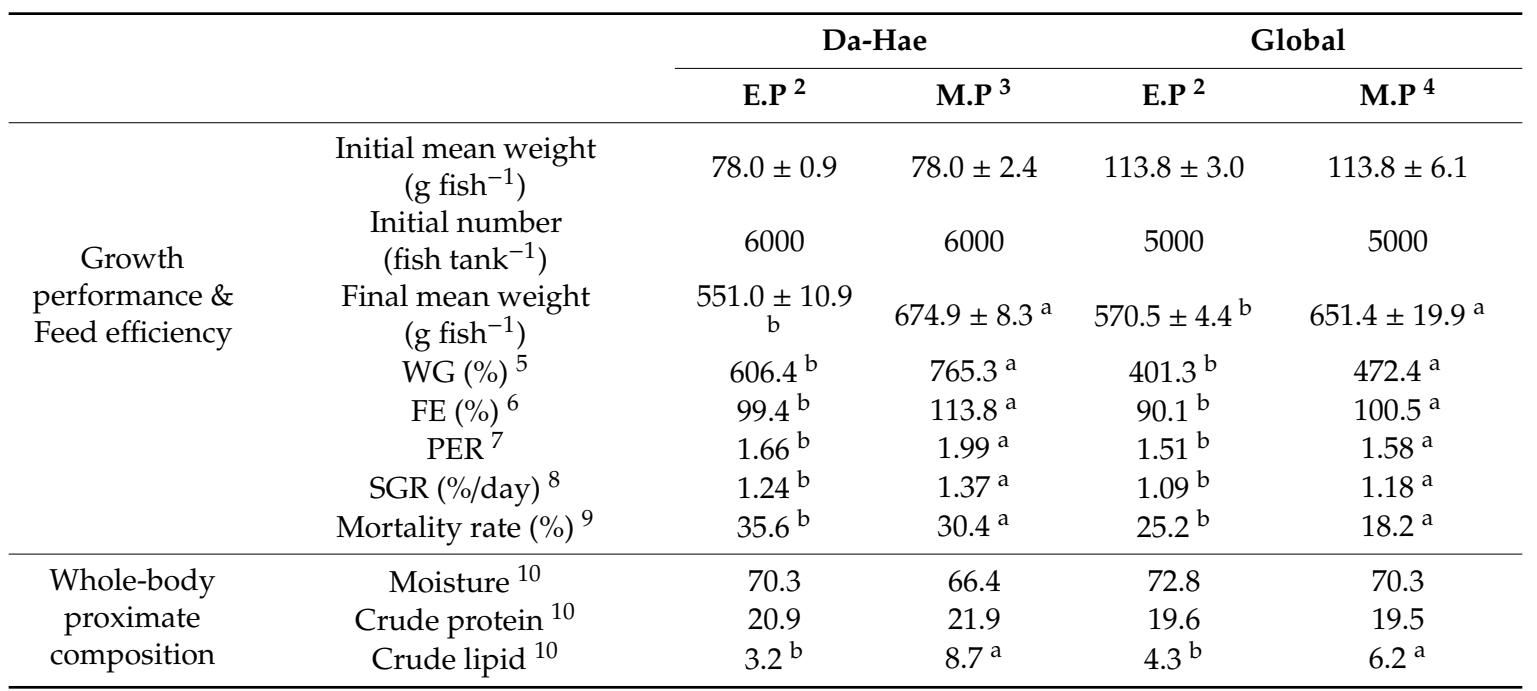

${ }^{1}$ Values are the mean of triplicate groups and presented as mean \pm SD. Values in the same row having different superscript letters $\left({ }^{a}, \mathrm{~b}\right)$ are significantly different $(p<0.05) .{ }^{2}$ Commercial feed containing $59.9 \%$ protein and $11.2 \%$ lipid, Republic of Korea. ${ }^{3}$ Raw fish feed (composed of mackerel and herring) containing $61.2 \%$ protein and $22.0 \%$ lipid. ${ }^{4}$ Raw fish feed (composed of mixed fish such as cutlass, jack mackerel, croaker, mackerel, and longsnout pricklebacks) containing $63.8 \%$ protein and $22.8 \%$ lipid. ${ }^{5}$ Weight gain $(\mathrm{WG}, \%)=($ final weight - initial weight) $\times$ $100 /$ initial weight. ${ }^{6}$ Feed efficiency ratio $($ FE, \% $)=($ wet weight gain/dry feed intake $) \times 100 .{ }^{7}$ Protein efficiency ratio $(\mathrm{PER})=$ wet weight gain/protein intake. ${ }^{8}$ Specific growth rate $(\mathrm{SGR}, \%)=($ loge final weight - loge initial weight $) \times$ 100/days. ${ }^{9}$ Mortality rate $(\%)=$ dead fish $\times 100 /$ initial total fish. ${ }^{10}$ Wet weight basis.

\section{Da-Hae}

(A)

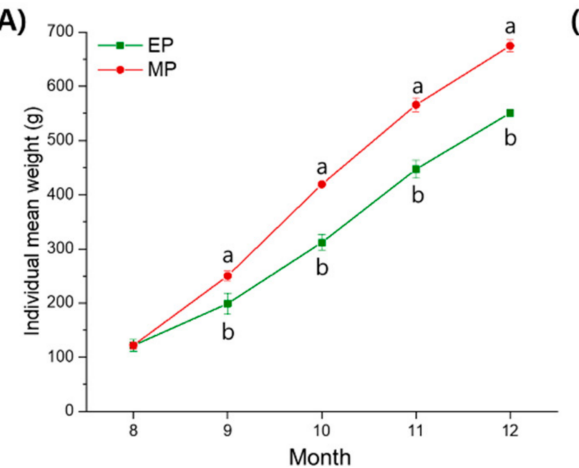

\section{Global}

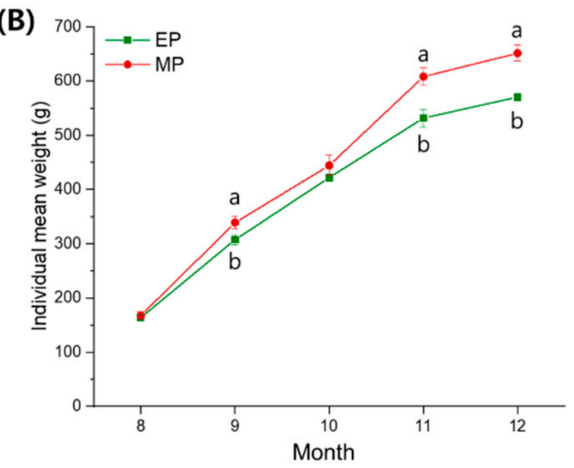

Figure 1. Cont. 

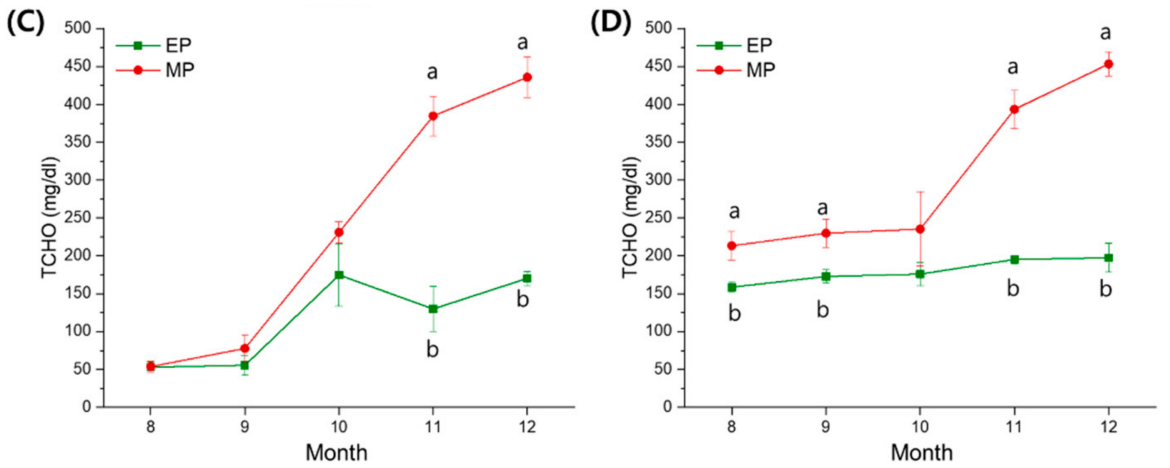

Figure 1. Variation of weight gain (WG) and total cholesterol (TCHO): (A,C) Da-Hae and (B,D) Global. Values are mean of triplicate groups and presented as mean \pm SD. Values having different superscript letters $\left({ }^{\mathrm{a}, \mathrm{b}}\right)$ are significantly different $(p<0.05)$.

Table 2. Formulation and proximate chemical compositions of experimental diets: extruded pellets (E.P) and moist pellets (M.P) ${ }^{1,2}$.

\begin{tabular}{lccc}
\hline & \multirow{2}{*}{ E.P $^{3}$} & \multicolumn{2}{c}{ M.P } \\
\cline { 3 - 4 } & & Da-Hae $^{4}$ & Global $^{\mathbf{5}}$ \\
\hline Ingredients (\%) & & \\
\hline Animal protein $^{6}$ & $>52$ & & \\
Plant protein $^{7}$ & $<33$ & & \\
Grains $^{8}$ & $<10$ & & \\
Additives & $>5$ & & \\
Raw fish & & $>80$ & $>80$ \\
Additives & & $>20$ & \\
\hline Proximate analysis (\%) & & & \\
$\quad$ Dry matter & $90.7^{\mathrm{a}}$ & $30.1^{\mathrm{b}}$ & $29.2^{\mathrm{b}}$ \\
Crude protein & 59.9 & 61.2 & 63.8 \\
$\quad$ Crude lipid & $11.2^{\mathrm{b}}$ & $22.0^{\mathrm{a}}$ & $22.8^{\mathrm{a}}$ \\
Ash & 12.8 & 13.8 & 12.6 \\
\hline
\end{tabular}

\footnotetext{
${ }^{1}$ Values are the mean of triplicate groups and presented as mean $\pm \mathrm{SD}$. Values in the same row having different superscript letters $\left({ }^{\mathrm{a}, \mathrm{b}}\right)$ are significantly different $(p<0.05) .{ }^{2}$ Dry matter basis. ${ }^{3}$ Commercial feed containing $59.9 \%$ protein and $11.2 \%$ lipid, Republic of Korea. ${ }^{4}$ Raw fish feed (composed of mackerel and herring) containing $61.2 \%$ protein and $22.0 \%$ lipid. ${ }^{5}$ Raw fish feed (composed of mixed fish such as cutlass, jack mackerel, croaker, mackerel, and longsnout pricklebacks) containing $63.8 \%$ protein and $22.8 \%$ lipid. ${ }^{6}$ Fishmeal, shrimp-, squid-, and meat-powder. ${ }^{7}$ Soybean, gluten, and yeast. ${ }^{8}$ Wheat flour. ${ }^{9}$ Vitamin, mineral, calcium phosphate lecithin, and choline chloride. ${ }^{10}$ Fishmeal, wheat flour, vitamin, mineral, etc. (farm-specific).
}

\subsection{Mortalities at Farms}

Pathogens (pathogenic microorganisms) causing mortality were monitored by the aquatic-animal disease center in charge of each farm. All of the fish deaths at both farms were caused by disease (Table 3). Similar mortal diseases at flounder farms, among the approximately 100 diseases found in Korean aquatic life since the 1980s [37,38], have been reported, most commonly as single instances or combinations of four bacterial diseases (Vibrio sp., Edwardsiella sp., Streptococcus sp., Flexibacter sp.) and two parasitic diseases (Scuticociliates, Emaciation disease). Vibrio sp., Edwardsiella sp., Streptococcus sp., and Scuticociliates arose in both the control and experimental groups at both farms, which were considered to have originated in the influx of natural, untreated seawater that is used at both farms. In particular, mortality caused by Lymphocystis disease (Figure 2A) occurred only in the control group, and mortality caused by abdominal inflation (Figure 2B) occurred only in the experimental group at both farms. This finding on Lymphocystis disease, that it had arisen only in the control group (M.P), possibly via inflow from the raw fish feed or via an infected carrier fish, is in contradiction to previous reports that Lymphocystis disease transmission occurs through the skin and gills of fish by 
direct contact or by waterborne exposure [39-41]. The present finding on abdominal inflation, that it arose only in the experimental group (E.P), could possibly have been related to the digestibility of the E.P diet, irrespective of earlier reports of abdominal inflation symptoms having been caused by Streptococcus sp. or Lactococcus sp. [42,43]. Further study, however, will be needed for accurate identification of the causes of disease in both cases (Lymphocystis disease and abdominal inflation).

Microorganisms are particularly sensitive to ambient temperature; that is, when the temperature is lower than is proper, catalytic activity is halted, deforming cells and inhibiting microorganism growth, whereas at higher-than-normal temperatures, enzymes, transport proteins, and other proteins are denatured, leading to cell-membrane decomposition [44,45]. Similar to the results of aquaculture disease monitoring conducted by the Korean government [14,42], the incidence rate of disease peaked at high water temperature and then decreased as the water temperature decreased (Figure 2C,D), this phenomenon is considered to have been due to the above-noted effect of temperature on microorganisms. Nevertheless, in January (water temperature $<10{ }^{\circ} \mathrm{C}$ ), mortality rarely occurred $(<10 \mathrm{fish} / \mathrm{month})$ in the control group (M.P), whereas in the experimental group (E.P), it occurred continuously ( $>100 \mathrm{fish} / \mathrm{month}$ ) due to the same reason (abdominal inflation symptoms) at both farms (Figure 2C,D), which is, as mentioned earlier, considered to be owed to the correlation between feed and digestibility.

Table 3. Disease status of olive flounder fed with experimental diets (E.P and M.P): "V" (positive) and "-" (negative).

\begin{tabular}{|c|c|c|c|c|c|c|c|c|c|c|c|c|c|}
\hline & & \multicolumn{2}{|c|}{ Aug } & \multicolumn{2}{|c|}{ Sep } & \multicolumn{2}{|c|}{ Oct } & \multicolumn{2}{|c|}{ Nov } & \multicolumn{2}{|c|}{ Dec } & \multicolumn{2}{|c|}{ Jan } \\
\hline & & E.P & M.P & E.P & M.P & E.P & M.P & E.P & M.P & E.P & M.P & E.P & M.P \\
\hline \multirow{7}{*}{ Da-Hae } & Scuticociliates & - & - & $\mathrm{V}$ & $\mathrm{V}$ & $\mathrm{V}$ & $\mathrm{V}$ & - & - & - & - & - & - \\
\hline & Vibrio sp. & $\mathrm{V}$ & $\mathrm{V}$ & $\mathrm{V}$ & $\mathrm{V}$ & $\mathrm{V}$ & $\mathrm{V}$ & - & - & - & - & - & - \\
\hline & Abdominal inflation & $\mathrm{V}$ & - & $\mathrm{V}$ & - & $\mathrm{V}$ & - & $\mathrm{V}$ & - & $\mathrm{V}$ & - & $\mathrm{V}$ & - \\
\hline & Lymphocystis & - & - & - & $\mathrm{V}$ & - & $\mathrm{V}$ & - & $\mathrm{V}$ & - & $\mathrm{V}$ & - & - \\
\hline & Edwardsiella sp. & $\mathrm{V}$ & $\mathrm{V}$ & $\mathrm{V}$ & $\mathrm{V}$ & $\mathrm{V}$ & $\mathrm{V}$ & - & - & - & - & - & - \\
\hline & Streptococcus sp. & - & - & $\mathrm{V}$ & $\mathrm{V}$ & $\mathrm{V}$ & $\mathrm{V}$ & $\mathrm{V}$ & $\mathrm{V}$ & - & - & - & - \\
\hline & Flexibacter sp. & - & - & - & - & $\mathrm{V}$ & $\mathrm{V}$ & - & - & - & - & - & - \\
\hline \multirow{7}{*}{ Global } & Scuticociliates & - & - & - & - & - & - & - & - & - & - & - & - \\
\hline & Vibrio sp. & $\mathrm{V}$ & $\mathrm{V}$ & $\mathrm{V}$ & $\mathrm{V}$ & - & - & - & - & - & - & - & - \\
\hline & Abdominal inflation & $\mathrm{V}$ & - & $\mathrm{V}$ & - & V & - & $\mathrm{V}$ & - & $\mathrm{V}$ & - & $\mathrm{V}$ & - \\
\hline & Lymphocystis & - & - & - & $\mathrm{V}$ & - & $\mathrm{V}$ & - & $\mathrm{V}$ & - & $\mathrm{V}$ & - & - \\
\hline & Edwardsiella sp. & $\mathrm{V}$ & $\mathrm{V}$ & $\mathrm{V}$ & $\mathrm{V}$ & - & - & - & - & - & - & - & - \\
\hline & Streptococcus sp. & - & - & $\mathrm{V}$ & $\mathrm{V}$ & V & $\mathrm{V}$ & V & $\mathrm{V}$ & - & - & - & - \\
\hline & Flexibacter sp. & - & - & - & - & - & - & - & - & - & - & - & - \\
\hline
\end{tabular}

(A)

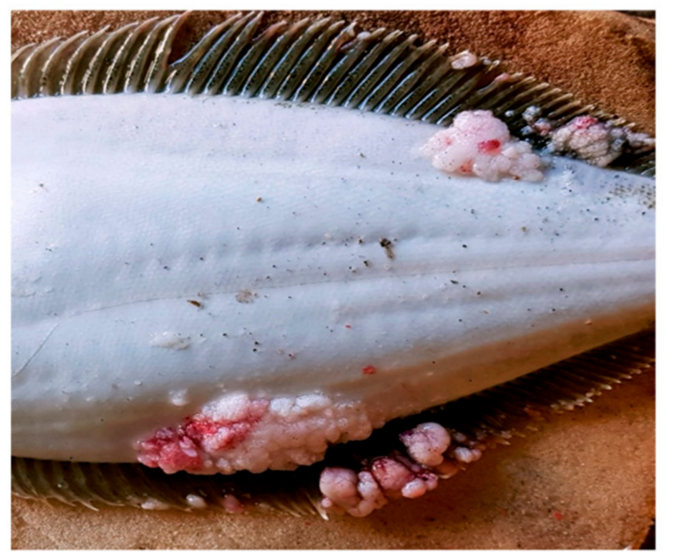

(B)

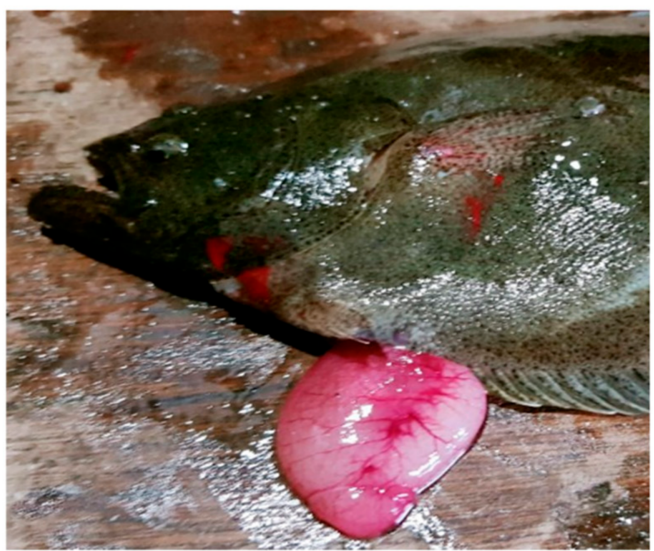

Figure 2. Cont. 

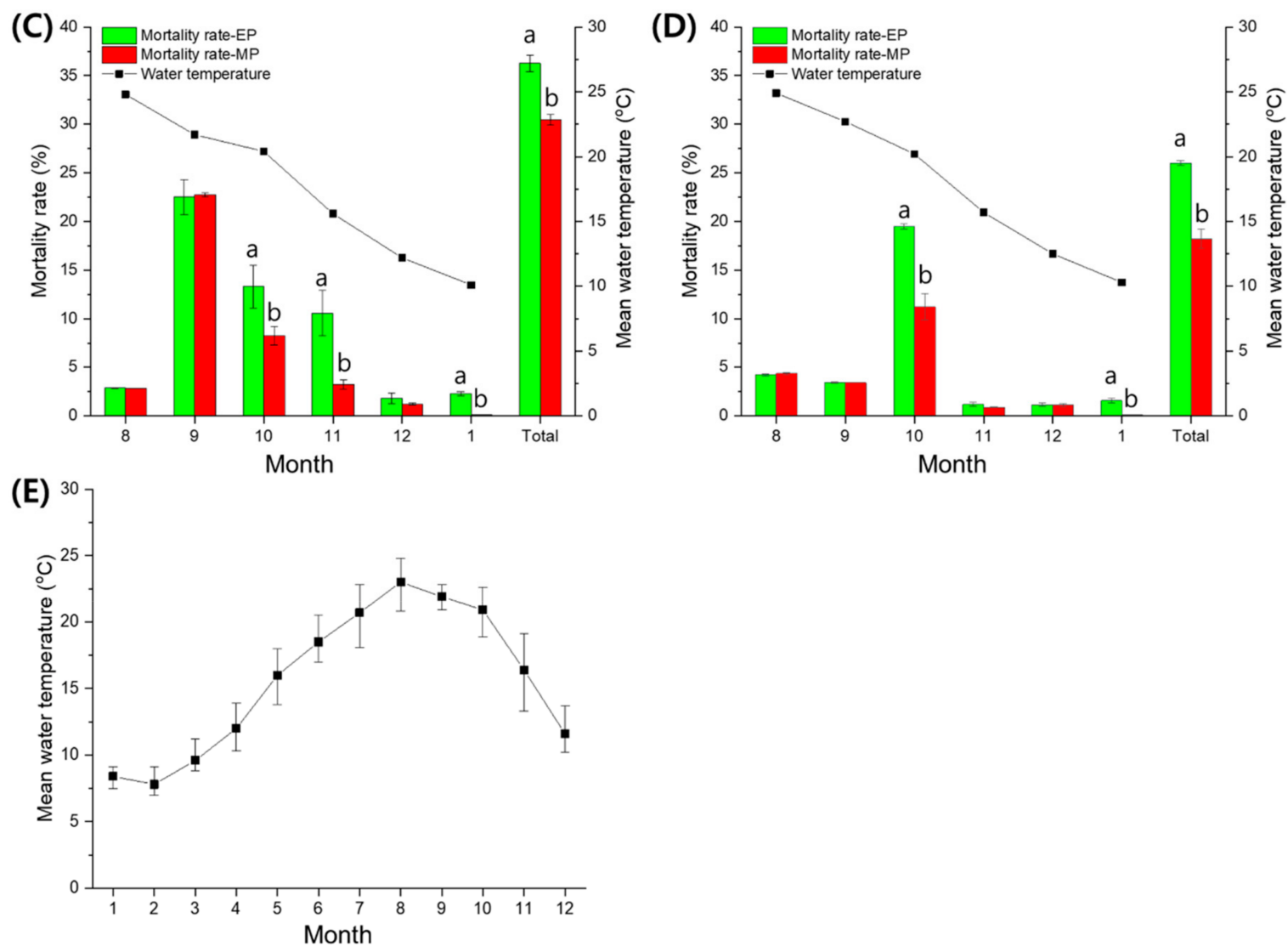

Figure 2. Morphological disease diagnoses of (A) Lymphocystis disease (M.P) and (B) abdominal inflation (E.P). Mortality rate and water temperature change in (C) Da-Hae and (D) Global. (E) Annual water temperature in Wando (Korea Hydrographic and Oceanographic Agency). Values are the mean of triplicate groups and are presented as mean \pm SD. Values having different superscript letters $\left({ }^{\mathrm{a}, \mathrm{b}}\right)$ are significantly different $(p<0.05)$.

\subsection{Histopathological Examination}

The results for hepatic fibrosis, steatosis (fatty change), inflammation, and necrosis or apoptosis of hepatocytes, as compared between flounder weight and feed (600-800 g, M.P and E.P) are shown in Figure 3. In the experimental group (E.P), microfragmented fat cells and balloon-shaped deformed adipocytes were observed weakly around the central vein, but showed a similar pattern to that of normal liver tissue (Figure 3A,B). On the other hand, in the control group (M.P), the nucleus was biased to one side, the cell body was enlarged, and transparent cytoplasmic vacuoles were clearly identified as adipocytes were lysed during Hematoxylin \& Eosin staining (Figure 3C,D). Neither portal inflammation, mononuclear cell collection, nor apoptosis was observed. Steatosis (fatty change or hepatocytic vacuolization), caused by abnormal accumulation of lipids in cells due to defects in the synthesis and removal of fat, was observed. Owing to the increase of adipocytes, normal hepatic parenchymal cells on the periphery of the hepatic central vein tended to be very few, whereas there appeared to be many round vacuoles in the form of lipids accumulated in the cytoplasm of hepatocytes, and tissues were contracted as dead hepatocytes had been removed by phagocytosis. In summation, the morphological differences of the flounder hepatocytes in the present study were considered to be due to the effects of the lipid content in feed, since the correlation between fat and hepatocytes is already known [46-48]. 
Da-Hae

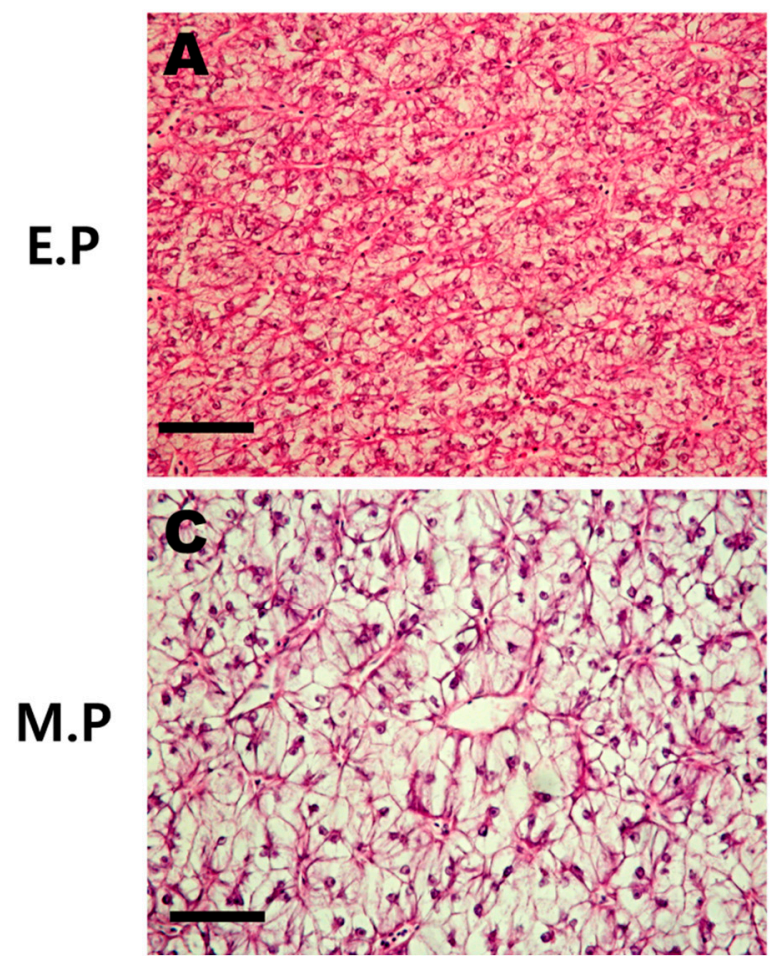

Global
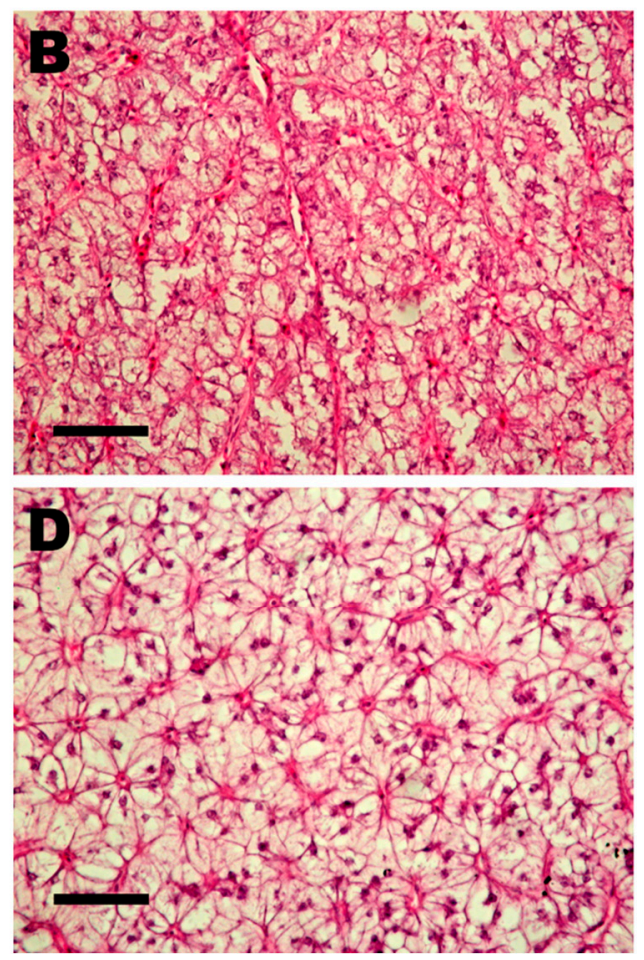

Figure 3. Optical-microscopy analysis of hepatocytes in liver tissue from olive flounder. Images representative of the sections of the steatosis group: $(\mathbf{A}, \mathbf{B})$ mixture of fatty change and cytoplasmic glycogen; (C,D) mild fatty change group. Hematoxylin \& Eosin staining, scale bars indicate $50 \mu \mathrm{m}(\times 400)$.

\subsection{Flounder Aquaculture in Korea}

Most flounder in Korea are produced on Jeju Island (22,171 metric ton, 59.5\%) and Wando (11,887 metric ton, $30.2 \%)$. The proper water temperature for flounder growth is $14-23^{\circ} \mathrm{C}$ [49-51]; the average annual seawater temperature on Jeju Island is $20^{\circ} \mathrm{C}\left(9-27.4{ }^{\circ} \mathrm{C}\right)$, and at Wando it is $15.6{ }^{\circ} \mathrm{C}$ (7-25 ${ }^{\circ} \mathrm{C}$, Figure 2E; water temperature varies in different areas of Wando) [3]. Jeju Island, where there is underground seawater (annual average water temperature $18^{\circ} \mathrm{C}$ ), can produce flounder all year round due to maintenance of water temperature by mixing with natural seawater depending on the season; Wando, though, is allowed approximately six months (May-July, September-November) of farming a year. Therefore, flounder farming to sale size (1-2 kg) takes approximately 15 months in Wando. In the meantime, Wando must pass through one winter $\left(<9^{\circ} \mathrm{C}\right.$, feeding $2-3$ times a week to maintain growth/life, most farms do not carry out normal operation) and two summers $\left(>24^{\circ} \mathrm{C}\right)$, during which time most cases of mortality occur. As for mortality in the present experiment, the numbers were 1047 at Da-Hae farm and 1167 at Global farm, with more fish dying in the E.P tanks than in the M.P tanks. By multiplying the number of deaths by selling prices, the economic losses were $\$ 9650$ and $\$ 10,756$, respectively.

In most flounder aquafarms using moist pellets (M.P) in Korea, it is common to use extruded pellets (E.P) for the fry period, and then to convert to moist pellets as fish enter the growing period. Past surveys of aquafarmers, including those at the present two farms using M.P pellets, showed, on the one hand, a distrust of the quality of E.P, especially with regard to its low digestibility after the fry period, and on the other hand, there was consensus on the need for feed conversion to E.P from M.P in the sense that the use of E.P would consequentially protect the marine environment in terms of prevention of the catching of small fish, fishery resources protection, and reduction of pollutants in effluents. Flounder producers in Korea have, as mentioned in the introduction, preferred to use 
M.P owing to its association with faster growth and lower mortality relative to E.P, despite their full awareness of the benefits of E.P, including nutritional value, easy feed storage/handing and feeding control, reduction of feeding time and workload, stable supply, and others. Therefore, development of flounder-exclusive formulated feed suitable for each growth stage and season as well as dissemination of more advanced feed manuals for improved digestion and absorption rate are considered to be urgent priorities. In the case of disease outbreak, there was a strong perception that it was not due to feed but rather to environmental impacts, especially water quality, which was supported by the fact that high mortality was observed in farms using untreated seawater, while low mortality was found in farms using treated water [14] (Figure 4). Therefore, a water-quality-improvement management plan should also be established urgently.

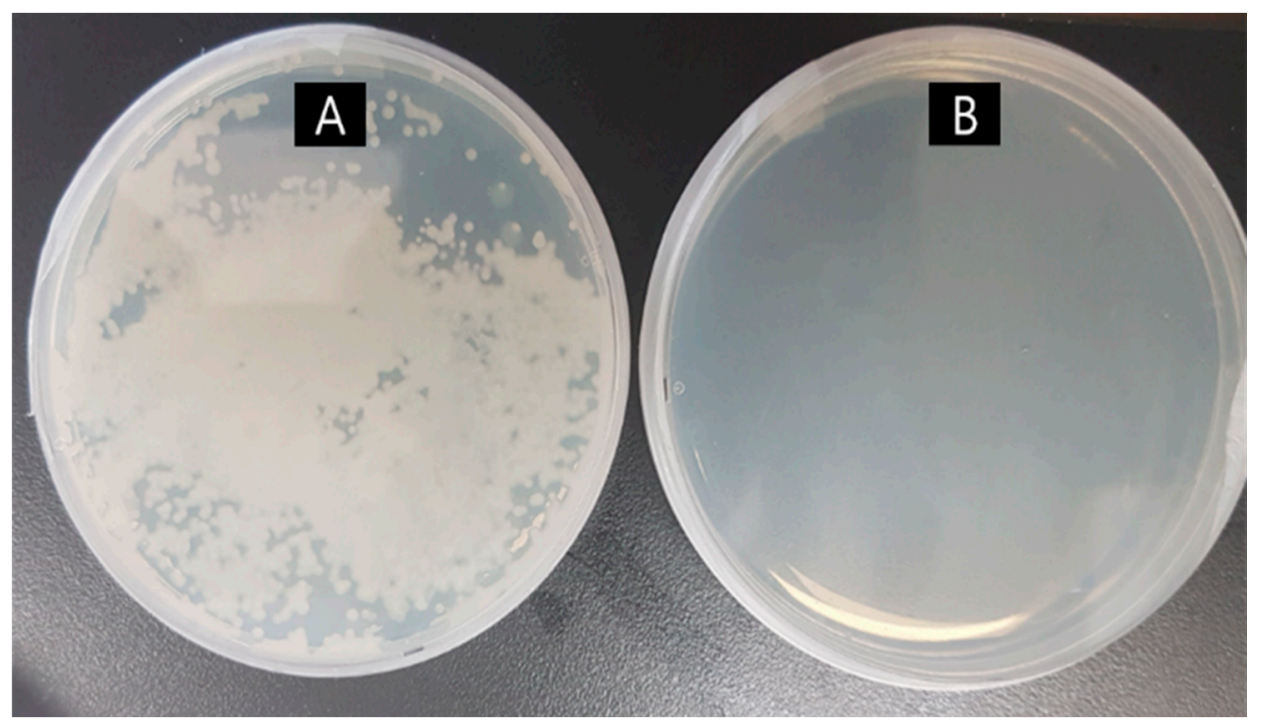

Figure 4. Electrolysis of natural seawater: (A) before and (B) after at Bi-bong Co., Ltd. $\left(33^{\circ} 18^{\prime} 28.9^{\prime \prime} \mathrm{N}\right.$ $126^{\circ} 49^{\prime} 35.5^{\prime \prime} \mathrm{E}$, Jeju island).

\section{Materials and Methods}

The analyses were performed in triplicate (at the minimum). All of the experimental procedures involving fish were performed in accordance with the guidelines approved by the Institutional Animal Care and Use Committee, Kunsan National University.

\subsection{Fish and Rearing Conditions}

The experiment was carried out at two local flounder farms in Wando, Republic of Korea, for six months (August, 2019 to January, 2020). The flounder were cultured in the traditional way at each farm. The same commercial diet exclusively for flounder containing $59.9 \%$ protein and $11.2 \%$ lipid (Republic of Korea) and raw fish feed containing 61.2\% (Da-Hae) or 63.8\% (Global) protein and 22.0\% (Da-Hae) or 22.8\% (Global) lipid, were supplied for six months at the two farms, but the sources of raw fish feed between the two farms (Da-Hae and Global) were different (Table 2). The dissolved oxygen (DO) level within the tanks was maintained at an average of 8 by utilizing liquid oxygen, and $100 \%$ natural seawater (without any water treatment) was used during the experiment. The water temperature in all of the tanks was maintained at the natural seawater temperature for the given month (from $24.9^{\circ} \mathrm{C}$ in August to $10.1{ }^{\circ} \mathrm{C}$ in January).

\subsubsection{Da-Hae Flounder Farm ( $34^{\circ} 17^{\prime} 31.9^{\prime \prime}$ N $126^{\circ} 45^{\prime} 21.7^{\prime \prime}$ E, Wando, Jeonnam Province)}

Growing flounder (Paralichthys olivaceus) averaging $78 \mathrm{~g}($ mean $\pm \mathrm{SD})$ were randomly distributed in triplicate for two treatments (6000 fish per 100 metric ton at $100 \mathrm{~m}^{2}$ tank/total 18,000 fish, Figure 5A). Commercial feed (E.P) was used for the experimental group, while raw fish feed (M.P, composed 
mainly of mackerel and herring) containing $61.2 \%$ protein and $22.0 \%$ lipid was supplied to the control group (Table 2). The fish were fed 2 times daily (9:00, 17:00) to apparent satiation at a rate of $0.82-2.14 \%$ of wet body weight per day for the 6-month duration of the experiment.

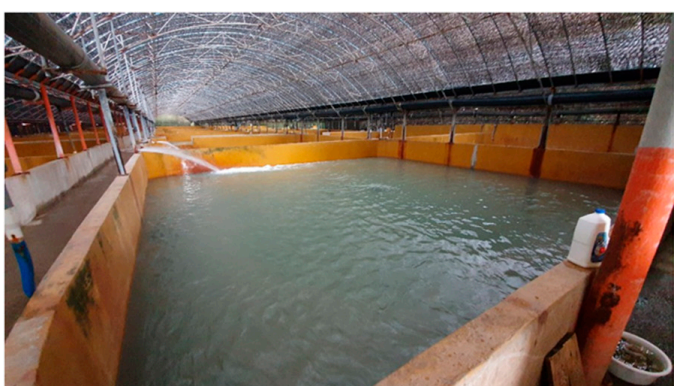

(A)

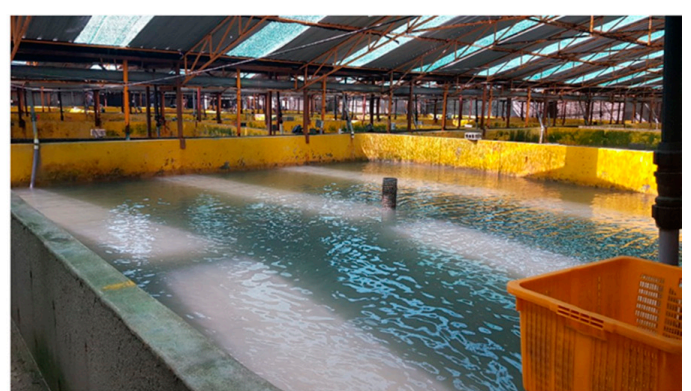

(B)

Figure 5. Experiment farms: (A) Da-Hae and (B) Global.

\subsubsection{Global Flounder Farm $\left(34^{\circ} 21^{\prime} 54.5^{\prime \prime} \mathrm{N} 126^{\circ} 53^{\prime} 21.5^{\prime \prime}\right.$ E, Wando, Jeonnam Province)}

Growing flounder (Paralichthys olivaceus) fish averaging $123.8 \mathrm{~g}$ (mean $\pm \mathrm{SD}$ ) were randomly distributed in triplicate to two treatments (5000 fish per 100 metric ton at $100 \mathrm{~m}^{2}$ tank/total 15,000 fish, Figure 5B). Commercial feed (E.P) was used for the experimental group, while raw fish feed (M.P, composed mainly of mixed fish such as cutlass, jack mackerel, croaker, mackerel, and longsnout pricklebacks) containing $63.8 \%$ protein and $22.8 \%$ lipid was supplied for the control group (Table 2). The fish were fed 2 times daily $(9: 00,17: 00)$ to apparent satiation at a rate of $0.49-2.34 \%$ of wet body weight per day for the 6-month duration of the experiment.

\subsection{Growth Performance and Analysis Methods}

A total of 500 fish were randomly selected monthly from each tank and weighed to determine the weight gain (WG), feed efficiency (FE), specific growth rate (SGR), and survival rate. At the end of the feeding trial, a proximate composition analysis of three fish randomly selected monthly from each tank and diets (E.P (monthly); MP (every 10 days)) at two farms was performed using the standard AOAC (Association of Official Analytical Chemists) methods [52]. Preparatorily, samples were freeze-dried for $48 \mathrm{~h}$. The moisture contents were determined using a dry oven at $105^{\circ} \mathrm{C}$, and the ash contents by means of combustion at $550{ }^{\circ} \mathrm{C}$. The crude protein was analyzed by the Kjedahl method, and the crude lipid was analyzed by soxhlet extraction using the soxhlet system 1046 (Tecator AB, Hoganas, Sweden) [53]. The activities of total cholesterol (TCHO-P) in serum (blood) were measured using a chemical analyzer (FujiDRI-CHEM 3500i, Fuji Photo Film, Ltd., Tokyo, Japan). The samples were allowed to clot at room temperature for $30 \mathrm{~min}$. Then, the serum was separated by $5000 \times g$ centrifugation (10 min).

\subsection{Histopathological Examination of Liver}

The fish were dissected to observe the overall external morphology (e.g., lesion appearance) and the health of the internal organs, and histological observation was performed by general staining after general tissue processing in order to identify the morphology of the cells and their changes. After anesthetization of the fish by 20 ppm of 2-phenoxyethanol (Sigma, St. Louis, Missouri, MO, USA) followed by dissection and tissue ablation, the liver was immersed in $10 \%$ neutral buffered formalin solution (Sigma, St. Louis, Missouri, MO, USA) for $24 \mathrm{~h}$. In addition, the paraffin was infiltrated, according to a conventional method, to produce a paraffin block. Each block was cut to a thickness of $5 \mu \mathrm{m}$ with a microtom (Leica, Wetzlar, Germany), and then the tissue sections were attached to slide glass coated with 3-aminopropyl triethoxysilane (Sigma, St. Louis, Missouri, MO, USA). The attached tissue sections were deparaffinized and hydrolyzed using xylene and ethanol in staged concentrations, followed by Hematoxylin \& Eosin staining. After staining, the tissue sections were dehydrated 
and cleared and then sealed using Synthetic Mountant (Shandon, Runcorn, UK). The stained tissue sections were observed under optical microscopy and photographed using a digital camera (Olympus, Tokyo, Japan).

\subsection{Statistical Analysis}

All of the data were analyzed by one-way ANOVA (SPSS Inc., Chicago, IL, USA) to test for the effects of the treatments. When a significant treatment effect was observed, a Tukey HSD test was applied for comparison of the means. The treatment effects were considered at the $5 \%$ level of significance $(p<0.05)$.

\section{Conclusions}

The objective of this study was to conduct field experiments comparing formulated (E.P) and raw-fish (M.P) feeds at two flounder aquaculture farms to obtain the basic data necessary for improving aquafarmers' awareness of feed-quality issues and firmly establish and expand the use of formulated feed. In the results, there were significant differences in growth performance and mortality rate/number between the two groups. The M.P group showed higher growth and lower mortality relative to the E.P group. All cases of mortality were caused by six kinds of disease, four of which (Vibrio sp., Edwardsiella sp., Streptococcus sp., and Scuticociliates) were found to be common to the two groups; Lymphocystis, meanwhile, occurred only with M.P group and abdominal inflation only with E.P at both farms. With total deaths of 1047 (Da-Hae) and 1,167 (Global), more fish died in the E.P tanks than M.P tanks. By multiplying the number of deaths by selling price, the economic losses were $\$ 9,650$ and $\$ 10,756$, respectively. Therefore, it should be considered an urgent priority to develop flounder-exclusive formulated feed (E.P) for improved digestion and absorption rate and also to establish a water-quality-improvement management plan.

Author Contributions: Conceptualization, B.-J.L. and K.-W.K.; Formal analysis, S.K. and K.K.; Investigation, J.-Y.J., S.K., and K.K.; Experimental progress, data curation, writing, J.-Y.J.; Supervision, H.-S.H. All authors have read and agreed to the published version of the manuscript.

Funding: This study was conducted by the National Institute of Fisheries Science (R2020014), Ministry of Ocean and Fisheries, Republic of Korea.

Conflicts of Interest: The authors declare no conflict of interest.

\section{References}

1. FAO. The State of World Fisheries and Aquaculture; Food and Agriculture Organization of the United Nations: Rome, Italy, 2002.

2. FAO. The State of World Fisheries and Aquaculture; Food and Agriculture Organization of the United Nations: Rome, Italy, 2016.

3. KOSTAT. Preliminary Results of the Survey on the Status of Fish Culture in 2017; Statistics Korea: Daejeon, Korea, 2018.

4. Min, B.H.; Kim, H.C.; Lee, J.H.; Noh, J.K.; An, H.S.; Park, C.J.; Choi, S.J.; Myeong, J.I. Comparison of growth parameters in selected and unselected strains of olive flounder Paralichthys olivaceus. Korean J. Fish. Aquat. Sci. 2010, 43, 457-461. [CrossRef]

5. Byung Hwa Min, J.-H.L.; Noh, J.-K.; Kim, H.C.; Park, C.-J.; Choi, S.J.; Myeong, J.-I. Hatching rate of eggs, and growth of larvae and juveniles from selected olive flounder, Paralichthys olivaceus. Dev. Reprod. 2009, 13, 239-247.

6. Kim, M.G.; Lee, C.; Shin, J.; Lee, B.J.; Kim, K.W.; Lee, K.J. Effects of fish meal replacement in extruded pellet diet on growth, feed utilization and digestibility in olive flounder Paralichthys olivaceus. Korean J. Fish. Aquat. Sci. 2019, 52, 149-158. [CrossRef]

7. Kim, S.-S.; Oh, D.-H.; Cho, S.-J.; Seo, S.-H.; Han, H.-S.; Lee, K.-J. Evaluation of Acid-concentrated Soybean Meal as a Fishmeal Replacement and its Digestibility in Diets for Juvenile Olive Flounder Paralichthys olivaceus. Korean J. Fish. Aquat. Sci. 2014, 47, 824-831. [CrossRef] 
8. Pham, M.A.; Lee, K.-J.; Lim, S.-J.; Park, K.-H. Evaluation of cottonseed and soybean meal as partial replacement for fishmeal in diets for juvenile Japanese flounder Paralichthys olivaceus. Fish. Sci. 2007, 73, 760-769. [CrossRef]

9. Son, S.G.; Kim, M.S.; Park, J.H.; Yoo, M.H.; Jeong, H.D. Bacterins to Prevent the Contamination of Vbrio vulnificus in the Flounder, Paralichthys olivaceus. Korean J. Fish. Aquat. Sci. 2002, 35, 1-7. [CrossRef]

10. Kwon, M.-G.; Hwang, J.Y.; Jung, S.H. The Efficacy and Safety on Combination Vaccines: Edwardsiella tarda, Streptococcus iniae and S. parauberis, in Olive flounder, Paralichthys olivaceus. J. Fish. Mar. Sci. Educ. 2014, 26, 1193-1200. [CrossRef]

11. Jeong, Y.-U.; Subramanian, D.; Yeoung-Hwan, J.; Kim, D.-H.; Park, S.-H.; Park, K.-i.; Lee, Y.-D.; Heo, M.-S. Protective efficiency of an inactivated vaccine against Streptococcus iniae in olive flounder, Paralichthys olivaceus. Arch. Pol. Fish. 2016, 24, 23-32. [CrossRef]

12. Lim, H.J.; Abdellaoui, N.; Kim, K.H. Effect of miR-155 as a molecular adjuvant of DNA vaccine against VHSV in olive flounder (Paralichthys olivaceus). Fish. Shellfish Immunol. 2019, 88, 225-230. [CrossRef]

13. Park, S.B.; Nho, S.W.; Jang, H.B.; Cha, I.S.; Kim, M.S.; Lee, W.-J.; Jung, T.S. Development of three-valent vaccine against streptococcal infections in olive flounder, Paralichthys olivaceus. Aquaculture 2016, 461, $25-31$. [CrossRef]

14. NIFS. Report on Mornitoring of the Pilot Project Used Extruded Pellet Feed in a Ground-Water Tank; National Institute of Fisheries Science: Busan, Korea, 2019.

15. NIFS. Report on Mornitoring of the Pilot Fish Farms in the Use Extruded Pellet Feed; National Institute of Fisheries Science: Busan, Korea, 2014.

16. Cho, J.H.; Lee, B.J.; Hur, S.W.; Lee, S.; Kim, K.W.; Lim, S.G.; Son, M.H. Effects of Extrusion Pressure and Feed Ingredient Particle Size on Growth Performance in Olive Flounder Paralichthys olivaceus. Korean J. Fish. Aquat. Sci. 2019, 52, 247-255. [CrossRef]

17. Kim, Y.S.; Kim, B.S.; Moon, T.S.; Lee, S.M. Utilization of defatted soybean meal as a substitute for fish meal in the diet of juvenile flounder (Paralichthys olivaceus). Korean J. Fish. Aquat. Sci. 2000, 33, 469-474.

18. NRC. Nutrient Requirements of Fish and Shrimp; National Research Council: Washington, DC, USA, 2011.

19. Webster, C.D.; Lim, C. Nutrient Requirements and Feeding of Finfish for Aquaculture; CABI Publishing: Alabama, AL, USA, 2002.

20. Kim, K.W.; Kim, K.D.; Son, M.H.; An, C.M. Evaluation of squid liver powder as a dietary protein source replacing fish meal in juvenile flounder, Paralichthys olivaceus. J. Fish. Mar. Sci. Educ. 2011, 23, 461-467.

21. Kim, K.W.; Wang, X.J.; Bai, S.C. Optimum dietary protein level for maximum growth of juvenile olive flounder Paralichthys olivaceus (Temminck et Schlegel). Aquac. Res. 2002, 33, 673-679. [CrossRef]

22. Lee, S.-M.; Park, C.-S.; Bang, I.-C. Dietary protein requirement of young Japanese flounder Paralichthys olivaceus. Fisheries Sci. 2002, 68, 158-164. [CrossRef]

23. Kim, K.; Wang, X.; Bai, S.C. Reevaluation of the dietary protein requirement of Japanese flounder Paralichthys olivaceus. J. World Aquac. Soc. 2003, 34, 133-139. [CrossRef]

24. Kim, K.-D.; Lee, S.-M. Requirement of dietary n-3 highly unsaturated fatty acids for juvenile flounder (Paralichthys olivaceus). Aquaculture 2004, 229, 315-323. [CrossRef]

25. Bae, K.-M.; Kim, K.-W.; Lee, S.-M. Evaluation of Rice Distillers Dried Grain as a Partial Replacement for Fish Meal in the Practical Diet of the Juvenile Olive Flounder Paralichthys olivaceus. Fish. Aquat. Sci. 2015, 18, 151-158. [CrossRef]

26. Khosravi, S.; Bui, H.T.D.; Herault, M.; Fournier, V.; Kim, K.-D.; Lee, B.-J.; Kim, K.-W.; Lee, K.-J. Supplementation of Protein Hydrolysates to a Low-fishmeal Diet Improves Growth and Health Status of Juvenile Olive Flounder, Paralichthys olivaceus. J. World Aquac. Soc. 2018, 49, 897-911. [CrossRef]

27. Niu, K.M.; Khosravi, S.; Kothari, D.; Lee, W.D.; Lim, J.M.; Lee, B.J.; Kim, K.W.; Lim, S.G.; Lee, S.M.; Kim, S.K. Effects of dietary multi-strain probiotics supplementation in a low fishmeal diet on growth performance, nutrient utilization, proximate composition, immune parameters, and gut microbiota of juvenile olive flounder (Paralichthys olivaceus). Fish. Shellfish Immunol. 2019, 93, 258-268. [CrossRef]

28. Kim, K.D.; Kang, Y.J.; Lee, J.Y.; Kim, K.W.; Choi, S.M. Effects of Dietary Protein and Lipid Levels on Growth and Body Composition of Sub-adult Flounder Paralichthys olivaceus During the Summer Season. J. Aquac. 2008, 21, 239-243. 
29. Kim, K.D.; Kang, Y.J.; Lee, H.M.; Kim, K.W.; Jang, M.S.; Choi, S.M. Effects of dietary protein and lipid levels on growth and body composition of subadult olive flounder, Paralichthys olivaceus, at a suboptimal water temperature. J. World Aquac. Soc. 2010, 41, 263-269. [CrossRef]

30. Kim, K.D.; Kang, Y.J.; Lee, H.M.; Kim, K.W.; Son, M.H. Effects of Protein and Lipid Levels in Extruded Pellets on the Growth and Body Composition of the Olive Flounder Paralichthys olivaceus during the Summer and Whiter Seasons. Fish. Aquat. Sci. 2009, 12, 104-110. [CrossRef]

31. Choi, J.; Seo, J.Y.; Lee, C.R.; Kim, K.D.; Kang, Y.J.; Lee, S.M. Effects of Protein and Lipid Levels of Extruded Pellet on Growth and Body Composition of Flounder, Paralichthys olivaceus. J. Aquac. 2006, 19, $299-304$.

32. Choi, S.M.; Kim, K.W.; Kang, Y.J.; Park, H.S.; Bai, S.C. Optimum dietary lipid level and feeding rates of extruded pellets in juvenile flounder Paralichthys olivaceus during the summer season. J. Aquac. 2008, 21, 244-251.

33. Claxton, A.J.; Jacobs, J.D.; Iribarren, C.; Welles, S.L.; Sidney, S.; Feingold, K.R. Association between serum total cholesterol and HIV infection in a high-risk cohort of young men. J. Acq. Immun. Defic. Synd. Hum. R. 1998, 17, 51-57. [CrossRef] [PubMed]

34. Ravnskov, U. High cholesterol may protect against infections and atherosclerosis. QJM 2003, 96, 927-934. [CrossRef]

35. Deng, J.; Kang, B.; Tao, L.; Rong, H.; Zhang, X. Effects of dietary cholesterol on antioxidant capacity, non-specific immune response, and resistance to Aeromonas hydrophila in rainbow trout (Oncorhynchus mykiss) fed soybean meal-based diets. Fish. Shellfish Immunol. 2013, 34, 324-331. [CrossRef]

36. Merendino, N.; d'Aquino, M.; Franci, O.; Gentili, V.; Tomassi, G. Cholesterol-rich diet enhances peripheral blood mononuclear cell proliferation, vitamin E, and glutathione levels in rabbits. J. Nutr. Biochem. 1998, 9 , 294-297. [CrossRef]

37. Shim, J.D.; Hwang, S.D.; Jang, S.Y.; Kim, T.W.; Jeong, J.M. Monitoring of the mortalities in oliver flounder (Paralichthys olivaceus) farms of Korea. J. Fish Pathol. 2019, 32, 29-35. [CrossRef]

38. Kim, S.M.; Jun, L.J.; Park, M.A.; Jung, S.H.; Jeong, H.D.; Jeong, J.B. Monitoring of Emaciation Disease in Cultured Olive Flounder Paralichthys olivaceus in Jeju (2010-2013), Korea. Korean J. Fish. Aquat. Sci. 2015, 48, 719-724. [CrossRef]

39. Bowser, P.R.; Wooster, G.A.; Getchell, R.G. Transmission of walleye dermal sarcoama and lymphocystis via waterborne exposure. J. Aquat. Anim. Health 1999, 11, 158-161. [CrossRef]

40. Valverde, E.J.; Labella, A.M.; Borrego, J.J.; Castro, D. Artemia spp., a Susceptible Host and Vector for Lymphocystis Disease Virus. Viruses 2019, 11, 506. [CrossRef] [PubMed]

41. Wolf, K. Fish Viruses and Fish Viral Diseases; Cornell University Press: New York, NY, USA, 1988.

42. Kim, D.H.; Heo, M.S. Characteristics and diagnostic methods of Streptococcosis causing disease in aquaculture. J. Life Sci. 2018, 28, 1118-1126. [CrossRef]

43. Kim, D.-H.; Heo, M.-S. Dietary effect of Bacillus subtilis MD-02 on Innate Immune Response and Disease Resistance in Olive Flounder, Paralichthys olivaceus. Microbiol. Biotechnol. Lett. 2019, 47, 132-138. [CrossRef]

44. Kim, K.; Hur, J.W.; Kim, S.; Jung, J.Y.; Han, H.S. Biological wastewater treatment: Comparison of heterotrophs (BFT) with autotrophs (ABFT) in aquaculture systems. Bioresour. Technol. 2020, 296, 122293. [CrossRef]

45. Willey, J.; Sherwood, L.; Woolverton, C. Prescott's Microbiology, 7th ed.; McGraw-Hill: New York, NY, USA, 2008.

46. Lu, K.-L.; Xu, W.-N.; Li, J.-Y.; Li, X.-F.; Huang, G.-Q.; Liu, W.-B. Alterations of liver histology and blood biochemistry in blunt snout bream Megalobrama amblycephala fed high-fat diets. Fish. Sci. 2013, 79, 661-671. [CrossRef]

47. Dai, W.; Wang, K.; Zheng, X.; Chen, X.; Zhang, W.; Zhang, Y.; Hou, J.; Liu, L. High fat plus high cholesterol diet lead to hepatic steatosis in zebrafish larvae: A novel model for screening anti-hepatic steatosis drugs. Nutr. Metab. (Lond.) 2015, 12, 42. [CrossRef]

48. Wang, X.; Li, Y.; Hou, C.; Gao, Y.; Wang, Y. Physiological and molecular changes in large yellow croaker (Pseudosciaena crocea R.) with high-fat diet-induced fatty liver disease. Aquac. Res. 2015, 46, $272-282$. [CrossRef]

49. Cho, S.H.; Lee, S.M.; Park, B.H.; Ji, S.C.; Choi, C.Y.; Lee, J.H.; Kim, Y.C.; Lee, J.H.; Oh, S.Y. Effect of daily feeding ratio on growth and body composition of subadult olive flounder, Paralichthys olivaceus, fed an extruded diet during the summer season. J. World Aquac. Soc. 2007, 38, 68-73. [CrossRef] 
50. Hu, J.; You, F.; Wang, Q.; Weng, S.; Liu, H.; Wang, L.; Zhang, P.J.; Tan, X. Transcriptional responses of olive flounder (Paralichthys olivaceus) to low temperature. PLoS ONE 2014, 9, e108582. [CrossRef] [PubMed]

51. Kim, S.; Kim, A.; Ma, S.; Lee, W.; Lee, S.; Yoon, D.; Kim, D.H.; Kim, S. Glutathione Injection Alleviates the Fluctuation of Metabolic Response under Thermal Stress in Olive Flounder, Paralichthys olivaceus. Metabolites 2019, 10, 3. [CrossRef] [PubMed]

52. AOAC. Official Methods of Analysis, 16th ed.; Association of Official Analytical Chemists: Rockville, MD, USA, 1995.

53. Folch, J.; Lees, M.; Stanley, G.S. A simple method for the isolation and purification of total lipides from animal tissues. J. Biol. Chem. 1957, 226, 497-509. [PubMed]

C 2020 by the authors. Licensee MDPI, Basel, Switzerland. This article is an open access article distributed under the terms and conditions of the Creative Commons Attribution (CC BY) license (http://creativecommons.org/licenses/by/4.0/). 